\title{
Observations on the Life History of the Barndoor Skate, Dipturus laevis, on Georges Bank (Western North Atlantic)
}

\author{
Todd Gedamke, William D. DuPaul and John A. Musick \\ Virginia Institute of Marine Science, College of William and Mary \\ P.O. Box 1346, Rt. 1208 Greate Rd., Gloucester Point, VA, 23062, USA
}

Gedamke, T., W. D. DuPaul, and J. A. Musick. 2005. Observations on the Life History of the Barndoor Skate, Dipturus laevis, on Georges Bank (Western North Atlantic). J. Northw. Atl. Fish. Sci., 35: 6778. doi:10.2960/J.v35.m512

\begin{abstract}
The barndoor skate (Dipturus laevis) has been reported to be close to extinction in parts of its northern range and is believed to be particularly vulnerable to fishing mortality due to its relatively large size. A lack of basic life history information, however, has hampered an accurate assessment and management of north Atlantic populations. In an attempt to fill this void, information was collected from 2310 specimens caught during commercial sea scallop dredging in the southern section of Georges Bank Closed Area II. Eighty-seven fish were determined to be mature from a visual inspection of reproductive tracts and the allometric growth of claspers, oviducal glands and developing ova. Sexual dimorphism was apparent in length at $50 \%$ maturity with females maturing at $116.3 \mathrm{~cm}$ and males at $107.9 \mathrm{~cm}$. A preliminary analysis of 118 vertebrae indicates faster growth $(k=0.14$ to 0.18$)$ and younger female maturation ( 6.5 to $7.2 \mathrm{yr}$ ) than previously believed. Thus, resilience of the barndoor skate to overfishing may be higher than recently assumed.
\end{abstract}

Key words: Dipturus laevis, Georges Bank, growth, life history, maturity, reproduction, skate

\section{Introduction}

The barndoor skate Dipturus laevis (Mitchill, 1817), is one of many skate and ray species caught as by-catch in finfish trawl and scallop dredges in the Northwest Atlantic. Until recently, this species has received little attention, due primarily to its low market value (Musick et al., 1999; Dulvy et al., 2000; Kulka et. al., MS 2002), until a recent study suggested its potential extinction (Casey and Myers, 1998). Casey and Myers (1998) reported that the barndoor skate, once a common by-catch species off southern Newfoundland, had become locally extirpated in parts of its northern range due to overfishing. They also contended that "long-term research surveys on the continental shelf between the Grand Banks of Newfoundland and southern New England reveal that....the barndoor skate.... is close to extinction (Casey and Myers, 1998)." Subsequent petitions to place the species on the U.S. National Marine Fisheries Service Endangered Species List and listing of the the barndoor skate as vulnerable by the IUCN (Union for the Conservation of Nature and Natural Resources) placed the barndoor skate in the middle of conservation and extinction risk debates (Diaz-Soltera, 1999; Musick et. al., 1999; NEFSC, 2000).

The barndoor skate is the largest member of the family Rajidae found in the northwestern Atlantic, reaching a maximum length of $152 \mathrm{~cm}$ and a weight of $20 \mathrm{~kg}$ (Bigelow and Schroeder, 1953a). The species is found from Cape Hatteras to the Grand Banks of Newfoundland, Gulf of St. Lawrence and Nova Scotia (Leim and Scott, 1966; McEachran and Musick, 1975). It ranges from shallow coastal waters to depths greater than $400 \mathrm{~m}$ and tolerates water temperatures of $1.2-20^{\circ} \mathrm{C}$ (Bigelow and Schroeder, 1953b; McEachran and Musick, 1975). Recent analysis of Canadian survey and commercial fisheries data suggests that the overall distribution of the species is far more extensive than originally thought both in terms of depth and northern range (Kulka et al., MS 2002; Simon et al., MS 2002). Barndoor skates were found as far north as the Labrador Shelf to $62^{\circ} \mathrm{N}$ and into depths of about 1600 $\mathrm{m}$ with significantly higher catch rates at depths below 450 m (Kulka et al., MS 2002; Simon et al., MS 2002). These studies strongly indicate that Casey and Myers (1998) used a data set that poorly sampled the overall distribution of barndoor skate and as such substantially underestimated the actual barndoor skate population.

Due primarily to their large size and therefore presumed late maturation, barndoor skates are believed to be particularly vulnerable to the effects of high levels of fishing mortality; however, very little information is available on the biology and ecology of the barndoor skate to make an accurate assessment. Elasmobranchs in general have relatively low reproductive rates and low intrinsic rates of population increase due to their late maturity and low fecundity (Hoenig and Gruber, 1990; Camhi et al., 1998; Walker and Hislop, 1998). 
This life history strategy relies on a relatively high survival of a few well-developed offspring and results in a direct and limiting relationship between the number of adults in the population and number of young-of-year. The pattern of more productive species, like that exhibited in most teleost fishes involves the highly variable survival of many fragile offspring and greater fluctuations in the relative number of surviving young-of-year. In both strategies, changes in environmental conditions or fishing pressure can result in the increased survival of offspring but the potential for a large recruitment event or a quick recovery from overfished or depressed populations is much lower in the less productive species. Compounding the effects of excessive fishing on recovery potential is the interrelationship of life history traits and the trend towards later maturity among the larger, less fecund species. This results in longer generation times, a greater chance of juvenescence, and a significant delay between a reduction of fishing mortality and an increase in the number of spawning adults. Holden (1973) and Brander (1981) have shown that differences in life history parameters of elasmobranchs, particularly size at maturity and overall body size, result in species-specific responses to fishing mortality. The European common skate (Dipturus batis) and at least four other North Sea skates have all undergone severe regional population declines due in part to their relatively large size, late maturation, low fecundity and resulting sensitivity to fishing mortality (Brander, 1981; Walker and Heessen, 1996; Dulvy et al., 2000), an affect less apparent in smaller species.

Understanding these life history traits and quantifying the age and growth parameters for individual species have been recognized as crucial in the risk assessment and management of marine fishes (Parent and Schrimi, 1995; Musick, 1999a, b). A recent stock assessment of the United States Northwest Atlantic skate complex (NEFSC, 2000) listed the three largest species; barndoor, winter (Leucoraja ocellata), and thorny skates (Amblyraja radiata), as overfished and identified a need for further studies of the age, growth, and reproduction of these species. Our recent work has focused on defining these critical life history parameters for the barndoor skate. This paper presents the first significant information on the life history of the barndoor skate collected from 2310 specimens in the western North Atlantic.

\section{Materials and Methods}

All of the specimens used in this study were collected onboard commercial scallop vessels fishing in the southern portion (south of $41^{\circ} 30^{\prime \prime} \mathrm{N}$ ) of Georges Bank Closed Area II. (Fig. 1). This area was closed to the use of mobile fishing gear in December of 1994 in an effort to rebuild groundfish stocks. Following five years of no fishing effort in this area, the southern portion of Closed Area II was opened to limited commercial scallop fishing in June of 1999. Data was collected on twelve trips between June and November of 1999, 2000, and 2001. Vessels fished with two 15-foot New Bedford style sea scallop dredges (Posgay, 1957) constructed with a 10 inch mesh twine top and either 3.5 or 4 inch ring bags. Gear was towed in $55-73 \mathrm{~m}$ of water at an average speed of $9.2 \mathrm{~km} / \mathrm{hr}$. A total of 1311 tows were made from seven different commercial vessels during 90 days at sea.

Although the barndoor skates were not a significant percentage of fish by-catch, we observed enough individuals to initiate a comprehensive study of the barndoor skate in Georges Bank Closed Area II. Positive identification of the barndoor, which has been a concern in some published material (McEachran and Musick, 1975), was assured by the senior author or trained staff from The Virginia Institute of Marine Science. The barndoor was easily recognized by its long rostrum, acute angle of the anterior margin of the disk, grey ventral surface, and mucous pores (Bigelow and Schroeder, 1953a).

Disk width (DW), disk length (DL) and total length (TL) measurements were taken from all individuals. Clasper length (CL) was also taken for all males and measured as described for clasper inner length in the FAO species catalogue (Compagno, 1984). TL was measured from the tip of the snout to the tip of the tail and was recorded for all but 230 individuals. For these, TL was calculated from the TL/DW relationship $(\mathrm{TL}=1.4115 \times$ DW $\left.-0.7741 ; n=2080 ; R^{2}=0.99\right)$ generated from the remaining specimens. Total length (TL) has been used throughout this report for ease in comparison to previously published literature on other skate species and elasmobranchs (Walker and Hislop, 1998; Frisk et al., 2001).

Specimens were measured as soon as possible following capture. After measurements were taken, specimens were dissected and sampled or marked and released to avoid duplicate records of the same individuals. Biological samples including vertebrae, gastrointestinal and reproductive tracts, and tissue samples were taken from a representative sub-sample of sizes and sexes. Reproductive tracts were preserved in $10 \%$ formalin and examined in a laboratory at the Virginia Institute of Marine Science in Gloucester Point, VA. This paper will focus primarily on information from morphometrics and the reproductive tracts in addition to preliminary results of an age and growth analysis. A more comprehensive analysis of age and growth, population genetics, and food habits will be addressed in later papers. 


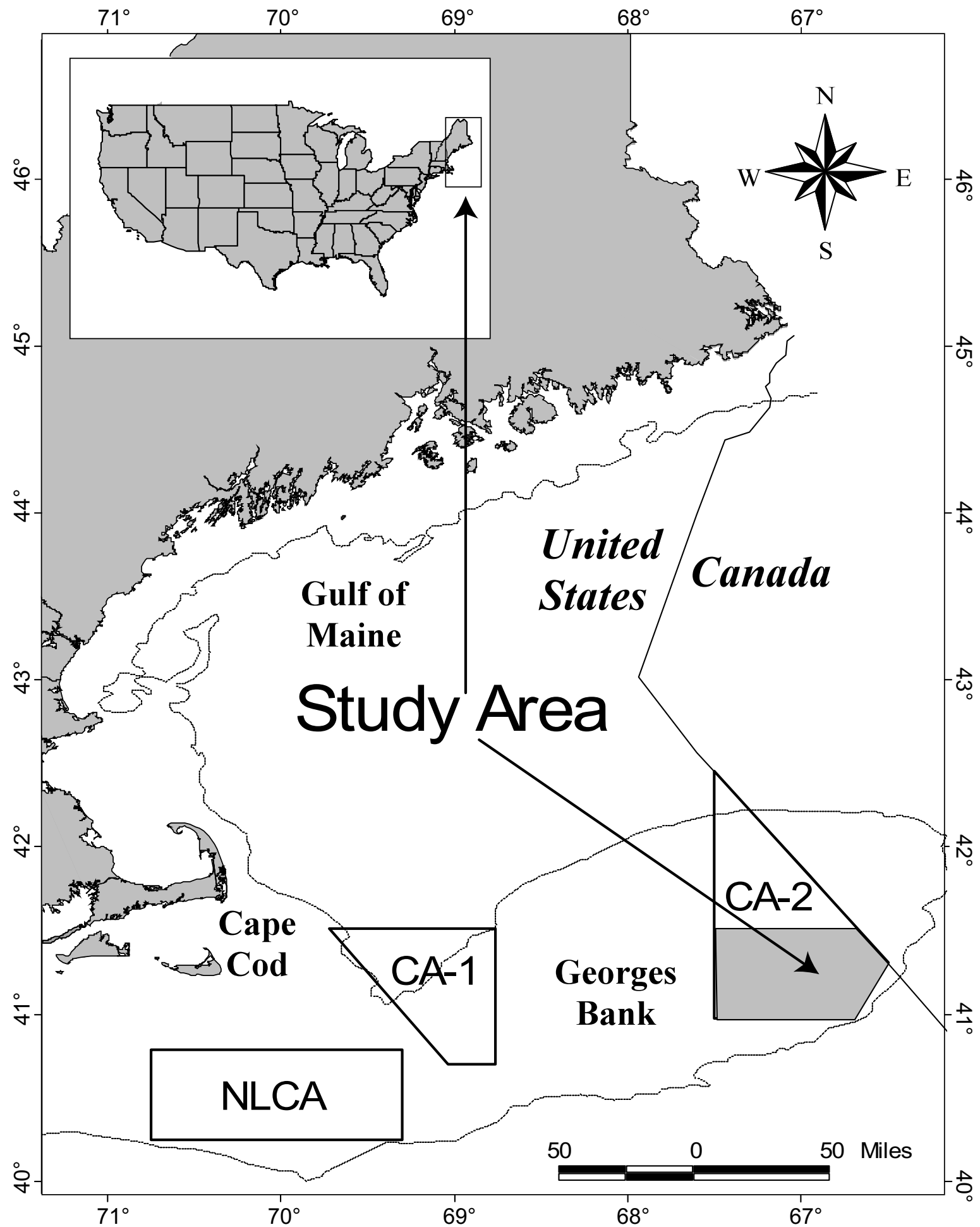

Fig. 1. Location of study site (CA-2 is Closed Area II, CA-1 is Closed Area I, NLCA is Nantucket Lightship Closed Area). 
Maturity. The allometric growth and expression of secondary sexual characteristics were utilized to determine the reproductive status of each individual and the size at maturity for each sex. Male barndoor skates were considered to be mature based on the following criteria: 1) an abrupt change in clasper length relative to total length (Babel, 1967; Struhsaker, 1969; Pratt, 1979); 2) the presence and degree of coiling in the vas deferentia (Pratt, 1979; Martin and Cailliet, 1988); 3) the internal morphology and the size, shape and appearance of the testes. Immature individuals had small flaccid testes that were homogenous in appearance while mature individuals had enlarged testes with visible differentiated follicles on the dorsal-lateral margins. Criterion 3 was only utilized in cases where coiling in vas deferentia was marginal.

The stage of sexual maturity in females was determined by: 1) the presence of developing or ripe eggs in the ovary (Holden, 1975; Pratt, 1979; Martin and Cailliet, 1988) and 2) the allometric growth of the oviducal gland (Pratt, 1979; Smale and Goosen, 1999). Individuals containing five large yolked eggs with a mean size $>10 \mathrm{~mm}$ were considered to be mature while individuals that contained white or clear eggs $<10 \mathrm{~mm}$ were judged to be immature. Oviducal gland measurements were taken across the widest part of the gland, generally perpendicular to the oviduct. Maturity was indicated by the accelerated growth of this organ as compared to total length.

Once individuals were classified as either mature or immature based on the criteria described above, the point of $50 \%$ maturity was calculated using a logistic probit analysis in Minitab (version 4.10.1998, Release 12). The phrase "length at maturity" will refer to the point of 50\% maturity throughout this paper.

Age and Growth. Vertebral samples $(n=639)$ were taken from a sub-sample of all sizes captured and frozen for later analysis. In the laboratory, samples were thawed, separated into individual centra, cleaned and then placed in $70 \% \mathrm{ETOH}$ for a minimum of 24 hours. Following this treatment, vertebral banding was apparent even with the naked eye suggesting that relatively simple techniques such as graphite microtopography (Neer and Cailliet, 2001) and/or oil immersion might be viable. Whole centrum ring counts were recorded on a number of specimens and then centra were sectioned through the focus along the central longitudinal axis using an Isomet rotary diamond saw (Buehler, 41 Lake Bluff, IL). If the remaining centrum half was large enough it was cut again or simply sanded to leave a bow-tie slice through the focus. Centra sections were then dried between two pieces of Plexiglas to prevent warping and mounted to microscope slides using Permount. Mounted sections were then sanded and polished with wet sandpaper (320, 400, then 600 grit) to approximately $0.5-1.0 \mathrm{~mm}$. Slides were then examined under a compound video microscope with the Optimus image analysis system (Media Cybernetics, 1999).

Banding patterns in the sectioned centra were apparent and similar to that described in Daiber (1960) for the clearnose skate, Raja eglanteria and by Waring (1984) for the little skate, Raja erinacea. Alternating wide and narrow bands were observed and hypothesized to be indicative of an annual cycle (Fig. 2). The narrow bands, henceforth called "growth rings" were counted to determine a putative age for each specimen. The first of these rings was generally faint, occurred at approximately $0.6-0.8 \mathrm{~mm}$ from the focus, and at the same location as an angle change and thickening of the corpus calcareum. This was considered to represent a birthmark and was consistent with observations from our smallest youngof-year specimens.

Growth rings were counted by at least two readers several times until a consensus was reached. Of the 639 vertebrae samples collected from 1999 to 2001, 118 have been processed, read by at least two readers and included in this paper. Although growth ring counts on whole centra appear consistent, only the results from the sectioned centra are presented in this paper. The effect of sample placement along the vertebral column, reader precision, or validation of the annual nature of the growth rings is in progress. Until such time as validation is complete, ages in this paper shall remain putative.

Age at maturity was calculated from specimens in which both vertebral banding and reproductive tracts were analyzed. A logistic probit analysis in Minitab (version 4.10.1998, Release 12) was utilized on the age/maturity data (mature individuals were assigned a 1 and immature a 0 ) to estimate the point of 50\% maturity. The von Bertalanffy growth function was then fit to all of the age-at length data with the PROC NLIN function in SAS (SAS, 1999). The von Bertalanffy growth function is:

$$
L_{t}=L_{\infty}\left[1-\exp \left(-k\left(t-t_{0}\right)\right)\right]
$$

where $L_{t}=$ length at age $L_{t}, L_{\infty}=$ asymptotic or maximum length, $k=$ growth coefficient, and $t_{0}=$ theoretical age when length equals zero. All of the smaller size-classes were well represented so back calculation of larger specimens was not necessary. Growth parameters were estimated for the sexes combined due to small sample sizes. 


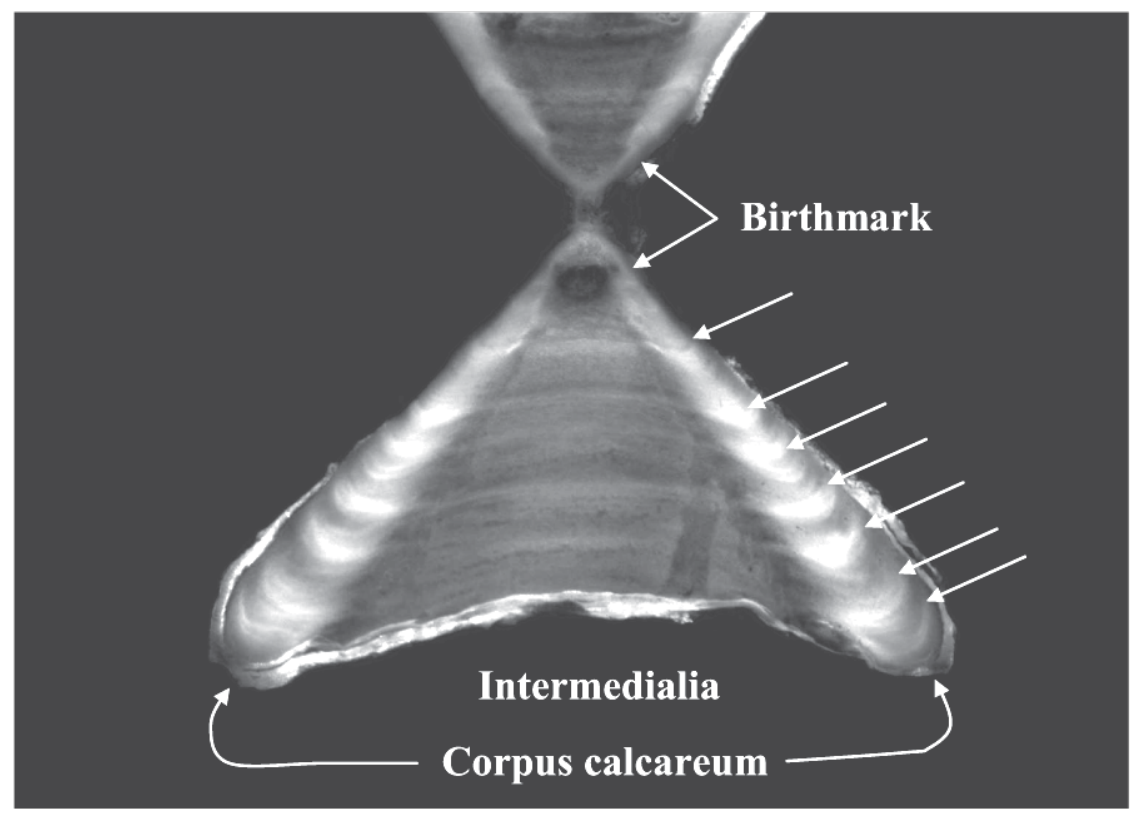

Fig. 2. Sectioned vertebral centrum from a 7-year-old barndoor skate. Arrows indicate growth rings. The slide was painted black to enhance image for publication.

\section{Results}

The sex ratio of all captured individuals was relatively even: 1181 females (51.1\%) and 1129 males (48.9\%). Total lengths ranged from $20.0-133.5 \mathrm{~cm}$ with an overall mean of $56.6 \mathrm{~cm}$ (Fig. 3). Catch rates increased each year over the course of the study but further spatial and length-specific analysis are necessary before any conclusions can be drawn. A total length-weight relationship was also generated (Weight in grams $=0.001125 \times(\mathrm{TL}$ in $\mathrm{cm})^{3.339} ; n=28$, and $R^{2}=0.97$ ) but should be used with caution because only 4 individuals greater than $80 \mathrm{~cm}$ were included in the weight samples.

Maturity. A logistic probit analysis on all individuals sampled estimated length at 50\% maturity at $112.4 \mathrm{~cm}$ (95\% CI's = 110.2-114.6 cm; $n=290)$, however, barndoor skates like many elasmobranchs exhibit sexual dimorphism in their development (Struhsaker, 1969; Holden, 1972; Gelsleichter, 1998). For the males, clasper lengths $(n=1126)$ and the examination of reproductive tracts from 148 specimens indicate the onset of adolescence at approximately $85-90 \mathrm{~cm}$. At this point, the ratio of clasper length to total length begins to noticeably change and then begins to dramatically increase at around $100 \mathrm{~cm}$ (Fig. 4). All specimens less than $103 \mathrm{~cm}$ were considered to be immature showing only minimal signs of development. Eighteen individuals between 82 and $113 \mathrm{~cm}$ had slightly enlarged testes and/or minimal coiling of the vas deferentia and were considered to be developing yet still immature. All individuals over $113 \mathrm{~cm}$ were mature, having highly coiled vas deferentia, large claspers, and enlarged testes with visible follicles. A total of 48 mature males were captured with a calculated length at maturity of $107.9 \mathrm{~cm}$ with $95 \%$ confidence intervals of $105.2-110.6$ cm (Table 1).

For the females, oviducal gland measurements and the examination of 142 reproductive tracts indicate that adolescence in female barndoor skates begins at approximately 90-95 cm (Fig. 5). The smallest individual with developing or ripe eggs indicating first maturity was observed at $114 \mathrm{~cm}$, with $100 \%$ maturity occurring at sizes greater than $124 \mathrm{~cm}$. Two females were captured with fully developed encapsulated eggs in each oviduct on November $10^{\text {th }} 1999(124 \mathrm{~cm})$ and on July $13^{\text {th }}, 2000$ $(121 \mathrm{~cm})$. A total of thirty-nine mature individuals were captured with the calculated length at maturity for the female barndoor skate of $116.3 \mathrm{~cm}$ with $95 \%$ confidence intervals of $114.2-118.5 \mathrm{~cm}$ (Table 1).

Age and Growth. Vertebrae samples were taken from fish that ranged from a $22 \mathrm{~cm}$ young-of-year male to a $133.5 \mathrm{~cm}$ female, the largest specimens captured. The relationship between TL and vertebral radius (VR) was significant supporting the use of vertebral sectioning for estimation of growth rates (Fig. 6). The oldest observed individuals were 11 years old. A size-at-age 


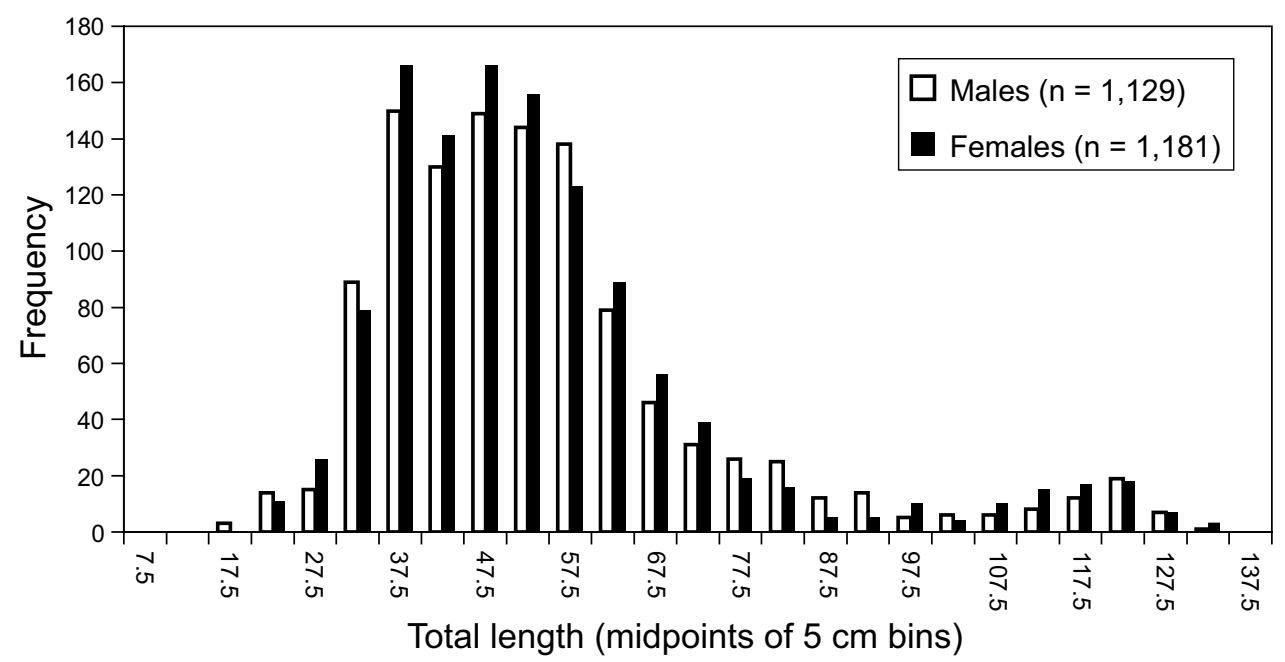

Fig. 3. Length-frequency histogram for all barndoor skates observed on Georges Bank from 1999-2001. Samples have been plotted in $5 \mathrm{~cm}$ bins $(n=2310)$.

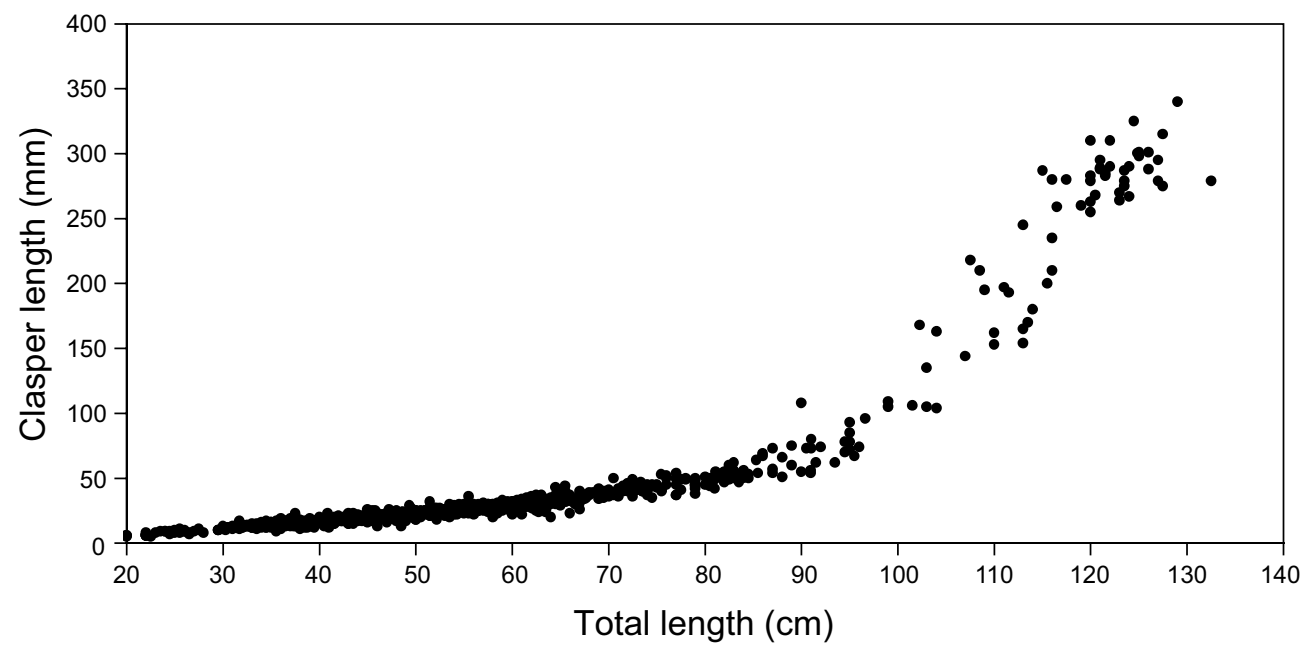

Fig. 4. Allometric relationship of clasper length to total length $(n=1126)$.

plot of all processed vertebral samples (sexes combined) was described well by the von Bertallanfy growth model (Fig. 7) with parameter estimates of: $L=166.3 \mathrm{~cm}, k=$ 0.1414 , and $t_{0}=-1.2912$.

The results of a probit analysis on those specimens where both age and maturity were assessed $(n=86)$ estimated the age at $50 \%$ maturity for males and females to be 5.8 and 6.5 years, respectively. Although samples sizes were relatively low $($ male $=51$, female $=35)$, the $95 \%$ confidence intervals were reasonably tight at $5.3-6.3$ years for males and 6.1-6.9 years for females (Table 1).
Substituting our length at maturity estimates for $L_{t}$ in the von Bertallanfy growth model and solving for age (t) then generated an alternate estimate of age at maturity. Estimates from this technique were slightly higher but very similar to those from the direct age/maturity probit analysis: 6.1 and 7.2 years for males and females respectively.

\section{Discussion}

Inspection of reproductive tracts and the allometric growth of secondary sexual structures provided an 
TABLE 1. Results of logarithmic probit analysis estimating length and age at 50\% maturity.

\begin{tabular}{lcccc}
\hline \hline Parameter being estimated & $\mathrm{N}$ & $\mathrm{N}($ mature) & 50\% Maturity estimate & 95\% Confidence Intervals \\
\hline Total Length: & & & $(\mathrm{cm})$ & $(\mathrm{cm})$ \\
Male & 148 & 48 & 107.9 & $105.2-110.6$ \\
Female & 142 & 39 & 116.3 & $114.2-118.5$ \\
Combined & 290 & 87 & 112.4 & $110.2-114.6$ \\
Age: & & & $($ years $)$ & $($ years $)$ \\
Male & 51 & 19 & 5.8 & $5.3-6.3$ \\
Female & 35 & 15 & 6.5 & $6.1-6.9$ \\
Combined & 86 & 34 & 6.0 & $5.7-6.3$ \\
\hline
\end{tabular}

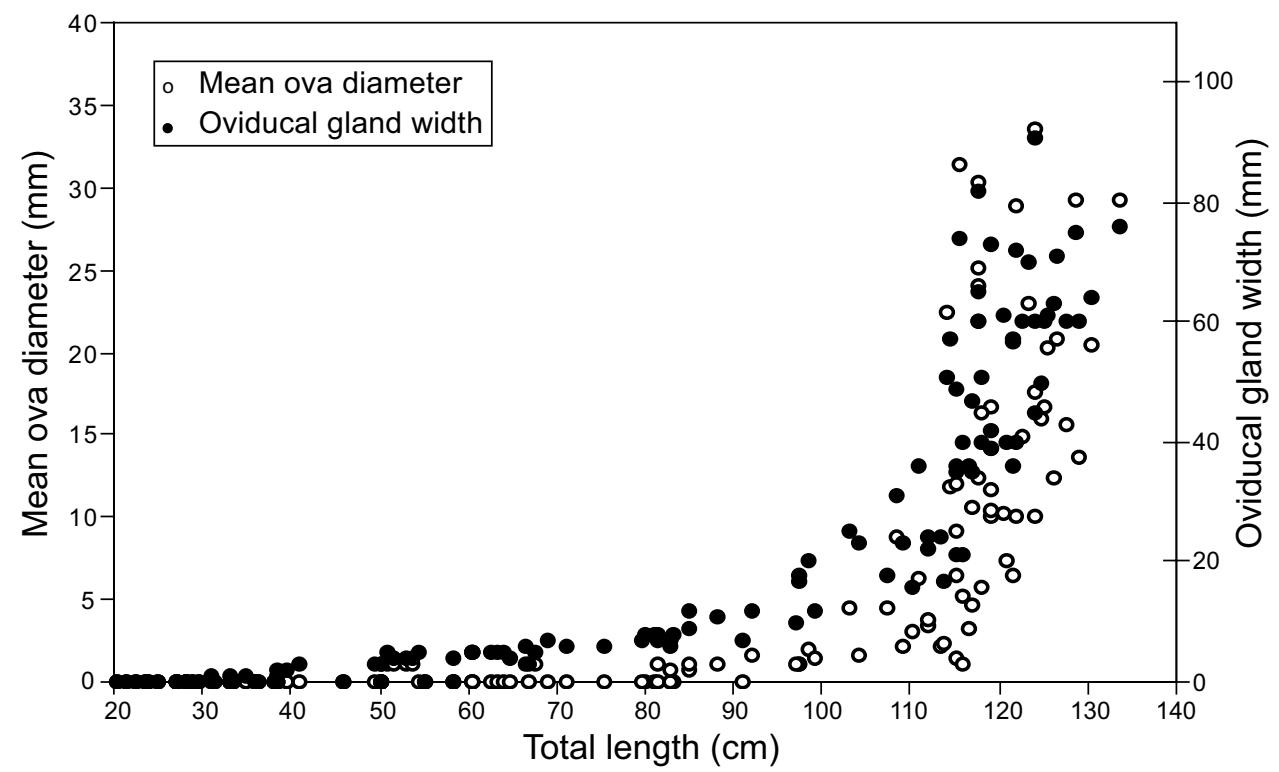

Fig. 5. Allometric relationship of mean ova diameter and oviducal gland width to total length for the female barndoor skate $(n=142)$.

easy means for quickly assessing maturity in sampled individuals. In male elasmobranchs, the development of claspers coincides with the differentiation of the testes (Wourms, 1977) and depending on the species, relative clasper length will increase either gradually or abruptly as an individual reaches sexual maturity (Pratt, 1979). As in several other batoid species, the growth of the claspers in the barndoor skate exhibited this type of easily identifiable abrupt change (Babel, 1967; Struhsaker, 1969). Accelerated clasper growth was observed between 100 and $120 \mathrm{~cm}$ providing obvious upper and lower bounds for our maturity estimate.

In female elasmobranchs, nearly every structure of the reproductive tract has been used as an indication of various stages of sexual development: the size shape and appearance of the ovary (Joung and Chen, 1995); the development of the oviduct (Springer, 1960), and the oviducal gland (Pratt, 1979; Smale and Goosen, 1999). In the barndoor skate, the allometric growth of the oviducal gland, which is a heart shaped organ where sperm may be stored, fertilization occurs and egg cases are produced, was a visually apparent and quantifiable indicator of the onset of adolescence. Significant maturation begins around $90 \mathrm{~cm}$ and was obviously nearing completion around $115 \mathrm{~cm}$ when large yolky eggs began appearing in a number of individuals.

Previously published values for length at maturity of the barndoor skate have been equivocal, making 


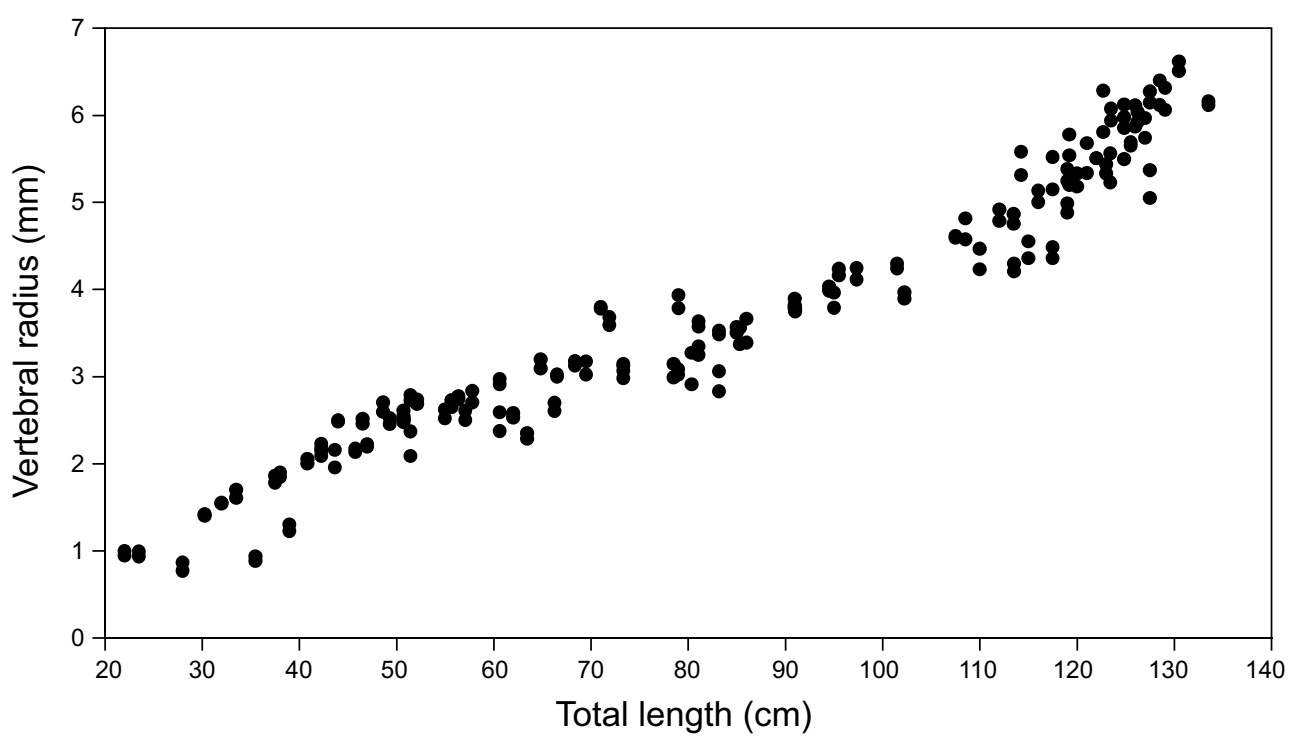

Fig. 6. Relationship of vertebral radius to total length $(n=118)$.

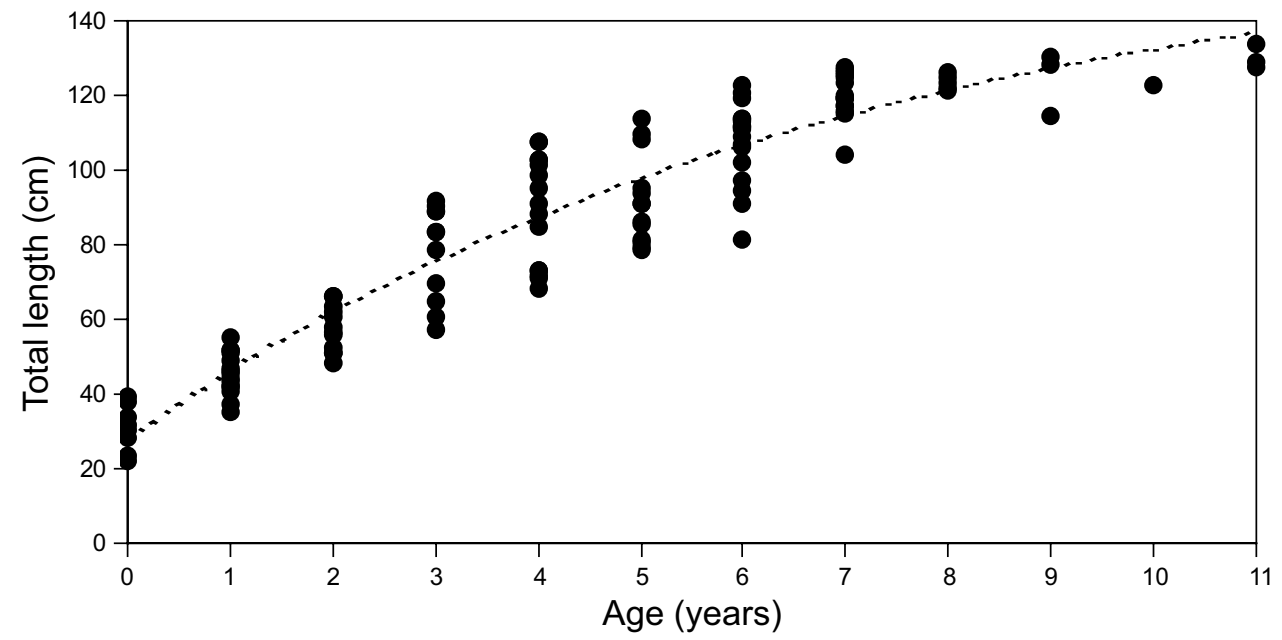

Fig. 7. Total length-at-age plot fitted with the von Bertallanfy growth curve $(n=118)$.

a comparison of our data to earlier findings difficult. Richards et al. (1963) reported a length at sexual maturity for the barndoor skate of $92 \mathrm{~cm}$, however the source, study site, and supporting information for this conclusion were not presented. Casey and Myers (1998) suggested that the barndoor may be similar to the European common skate (D. batis) and utilized the life history parameters of this species (age at maturity $\left(A_{\text {mat }}\right)=11 \mathrm{yrs}$, and fecundity $(\mathrm{F})=47$ eggs) in reaching their conclusions. A recent stock assessment of the seven skate species found in the north Atlantic United States waters (NEFSC, 2000) used a maximum observed length of $136 \mathrm{~cm}$ and predictive equations to generate estimates of length at maturity $\left(L_{\text {mat }}\right)$ of $102 \mathrm{~cm}$ and $A_{\text {mat }}$ of 8 years (Frisk et al., 2001). The results of the present study however show that female barndoor skates on the eastern end of Georges Bank reach sexual maturity at a larger size $\left(L_{\text {mat }}=116.3\right)$ and suggest sexual dimorphism in length at maturity.

The findings of this study also suggest that the barndoor skate matures at a similar point in their development as other female elasmobranchs. Holden (1974) suggested that the mean length of maturity for female elasmobranchs occurs at $60-90 \%$ of their asymptotic length. This ratio 
$\left(L_{\text {mat }} / L_{\text {max }}\right)$ can then be used to compare reproductive life history strategies among species. If $L_{\max }$ is taken to be $152 \mathrm{~cm}$, which is the largest individual ever recorded, the female barndoor skates in our study matured at a $L_{\operatorname{mat}} / L_{\max }$ ratio of 0.76 . This is comparable to values reported in other studies that have shown this ratio to be 0.74 for Raja eglanteria, 0.73-0.81 for Leucoraja erinacea, and 0.80 for Raja clavata (Fitz and Daiber, 1963; Holden, 1974; Waring, 1984). For the seven species common to the northwest Atlantic, observed and predicted $L_{\text {mat }}$ and $L_{\max }$ values used in the $30^{\text {th }}$ SAW (NEFSC, 2000; Frisk et al., 2001) result in $L_{\text {mat }} / L_{\text {max }}$ ratios of $0.52-0.81$.

Although there appears to be some variability in the exact timing of ring and growth band formation, vertebral growth patterns have been successfully used in a number of different elasmobranch age and growth studies (Holden and Vince, 1973; Pratt and Casey, 1983; Ryland and Ajayi, 1984). For the barndoor skate, the validation of annual ring formation has not been accomplished, however the validity of this technique has been demonstrated for at least five other similar skate species. Studies on Raja erinacea (Natanson, 1993), Raja microocellata (Ryland and Ajayi, 1984), Raja eglanteria (Gelseichter, 1998), Raja montagui (Ryland and Ajayi, 1984) and Raja clavata (Holden and Vince, 1973; Ryland and Ajayi, 1984) have utilized biological markers, such as the antibiotic tetracycline, to successfully validate the formation of annual rings. Although a few studies on shark species have proposed that bands may form twice a year (Pratt and Casey, 1983) or may be related to somatic growth (Natanson and Cailliet, 1990), there is no evidence from skate species closely related to the barndoor skate to suggest any pattern other than an annual cycle.

The application of the von Bertallanfy growth model to our age-at-size data provides a theoretical maximum total length $\left(L_{\infty}\right)$ of $166.3 \mathrm{~cm}$ and a growth coefficient $(k)$ of 0.14. Although these values are comparable to those found in other skate species (Table 2) and our samples covered the known size range, $L_{\infty}$ may be slightly overestimated due to low sample numbers in the oldest age classes. If we consider the largest barndoor skate ever reported $(152 \mathrm{~cm})$ (Bigelow and Schroeder, 1953a) and the largest individual recorded on Georges Bank since $1963(136 \mathrm{~cm})(\mathrm{NEFSC}, 2000)$ our estimate of $L_{\infty}$ appears slightly high. When the von Bertallanfy growth model is fit to our data with an assumed $L_{\infty}$ of $150 \mathrm{~cm}$ the growth coefficient (k) increases to 0.18 .

These empirically derived growth rates and the corresponding age at maturity estimates suggest that the barndoor skate may not be as susceptible to fishing pressure as recently assumed. Lacking direct information, Casey and Myers (1998) chose to use the life history parameters of the common skate, D. batis, in their discussion. The common skate reaches a maximum length of nearly $90 \mathrm{~cm}$ greater than the barndoor skate suggesting $k$ values of near 0.05 and an age at maturity estimate of 11 years. Skate species such as Raja clavata, R. microocellata, $R$. brachyura, or Leucoraja ocellata, which reach maximum sizes within $25-60 \mathrm{~cm}$ of the barndoor skate, would have served as important additional comparative species. Growth coefficients have been estimated between 0.07 and 0.22 for these species with estimates of age at maturity of around 5 or 6 years. As expected by maximum size alone, the barndoor skate matures at the high end of the age range for these smaller skates and well below that of D. batis.

Although these types of comparisons can provide guidance in situations where no direct information is available, differences in the life history strategies of even closely related species can lead to significant variability in parameter estimates. Stock assessments and subsequent management decisions should reflect the potential uncertainty inherent in these generalizations. Further research on the barndoor skate including histology of reproductive organs and annual ring validation are in progress to yield a more comprehensive life history analysis; however, we are confident that both our maturity and age-growth estimates will withstand further scrutiny.

The prudent application of our results to stock assessments and management decisions should consider the limitations of our study. Samples were taken from a very small area located in both the southern and shallow ends of the species distribution. At higher latitudes or at greater depths where water temperatures would be lower, growth may be slowed and age at maturity delayed. Under these circumstances, our age at maturity and growth rate estimates are likely to be negatively biased and might overestimate the potential productivity of a regional population. Another factor that might suggest a conservative application of our results is the unknown catchability of our sampling gear. Commercial scallop dredges, like many other fishing gears, are likely to be biased against catching large individuals. Although our data do not show a large size range within older cohorts, this scenario might result in the underestimation of age at maturity. It is also probable that this same selective fishing pressure over long periods of time would result in a reduction of both maximum age and age at maturity in comparison to a virgin population. This theory is supported by the absence of individuals as large as those reported by Bigelow and Schroeder (1953a) some 50 years ago. 
TABLE 2. Summary of von Bertallanfy growth coefficients $(k)$ and maximum size $\left(L_{\infty}\right)$ estimated for select skate species. Sexes were combined to generate estimates unless otherwise indicated.

\begin{tabular}{|c|c|c|c|}
\hline Species & $L_{\infty}(\mathrm{cm})$ & $k$ & Reference \\
\hline Dipturus batis & 253.7 & 0.06 & Du Buit, 1977 \\
\hline Dipturus laevis & 166.3 & 0.14 & This Study \\
\hline \multirow[t]{4}{*}{ Raja clavata } & 139.2 & 0.09 & Ryland and Ajayi, 1984 \\
\hline & 105 & 0.21 & Brander and Palmer, 1985 \\
\hline & 107.0 우 & 0.13 우 & Holden, 1972 \\
\hline & $85.60^{\circ}$ & $0.210^{\circ}$ & \\
\hline \multirow[t]{2}{*}{ Raja microcellata } & 137.0 & 0.07 & Ryland and Ajayi, 1984 \\
\hline & $115.00^{\circ}$ & 0.19 우 & \\
\hline Raja brachyura & 118.4 우 & $0.190^{\circ}$ & Holden, 1972 \\
\hline Leucoraja ocellata & 114.1 & 0.14 & Simon and Frank, 1996 \\
\hline \multirow[t]{2}{*}{ Raja eglantera } & 104.2 우 & 0.17 우 & Gelsleichter, 1998 \\
\hline & $95.50^{\circ}$ & $0.190^{\circ}$ & \\
\hline Leucoraja erinacea & 52.7 & 0.35 & Waring, 1984 \\
\hline \multirow[t]{3}{*}{ Raja montagui } & 97.8 & 0.15 & Ryland and Ajayi, 1984 \\
\hline & 72.8 우 & 0.19 우 & Holden, 1972 \\
\hline & $68.70^{\circ}$ & $0.180^{\circ}$ & \\
\hline
\end{tabular}

Finally, samples were collected during the six-month period of June through November with similar bimodal length frequency catch curves observed in all three years of the study. While there is no evidence to support that any of our parameter estimates are biased as a result, the persistent bimodal nature of our length frequency data suggests size-specific migrations out of the sampled area or a potential mixing of two different stocks rather than simply changes in recruitment. Although one would not expect the effect to be large it is impossible to determine the presence, magnitude, or direction of any bias in parameter estimates without further work to determine if seasonal migrations are occurring and to what degree.

The lack of species-specific information and failure to review historical data has allowed the decline of species such as the barndoor skate (Casey and Myers, 1998), common skate (Dipturus batis) (Brander, 1981), longnose skate (Dipturus oxyrhinchus) (Dulvy et al., 2000) and the white skate (Rostroraja alba) (Dulvy et al., 2000) to occur virtually unnoticed for long periods of time. Our results coupled with the relatively large numbers of observed animals and the recent increase in research survey biomass estimates (NEFSC, 2000) suggest that the barndoor skate may be more resilient to overfishing than previously believed and that the extinction of the species on the eastern Georges Bank is not imminent. Regardless, the life history strategy of this elasmobranch still renders it much more vulnerable to overharvest than the vast majority of bony fishes.

\section{Acknowledgements}

We thank D. Rudders, J.D. Lange Jr., B. Carroll, and R. Harshbarger for their collection efforts at sea and the captain and crews of the F/V Celtic, F/V Alpha Omega, F/V Barbara Ann, F/V Heritage, F/V Tradition, F/V Endeavor, and the F/V Mary Anne. A special thanks goes out to Captain C. Quinn of the F/V Celtic for his assistance during the course of this study. We would also like to thank John Hoenig, David Kulka, Nick Dulvy, and one anonymous reviewer for their helpful comments on earlier versions of this manuscript.

This research has been made possible by funds generated from the one percent set-aside of the scallop total allowable catch (TAC) under Framework adjustment 13 to the New England Fishery Management Councils Atlantic sea scallop fishery management plan (FMP) and Framework adjustment 34 to the Northeast multispecies FMP. This is contribution No. 2559 from the Virginia Institute of Marine Science.

\section{References}

BABEL, J. S. 1967. Reproduction, life history and ecology of the round stingray Urolophus halleri Cooper. Calif. Dept. Fish Game, Fish Bull., 137: 1-104.

BIGELOW, H. B. and W. C. SCHROEDER. 1953a. Fishes of the Gulf of Maine. Fish. Bull., U.S., 74(53).

1953b. Fishes of the western North Atlantic. Sawfishes, guitarfishes, skates and rays. Mem. Sears Found. Mar. Res., 
1(2). Yale Univ., New Haven, 1(2), 588 p.

BRANDER, K. 1981. Disappearance of Common skate Raia batis from Irish Sea. Nature, 290: 48-49.

BRANDER, R. and D. PALMER. 1985. Growth rate of Raia clavata in the Northeast Irish Sea. ICES J. Cons., 42: $125-128$.

CAMHI, M., S. FOWLER, J. MUSICK, A. BRÄUTIGAM and S. FORDHAM. 1998. Sharks and their relatives: ecology and conservation. Occas. Pap. IUCN Species Surviv. Comm., 20. iv +39 p.

CASEY, J. M. and R. A. MYERS. 1998. Near extinction of a large, widely distributed fish. Science, 281: 690-692.

COMPAGNO, L. J. V. 1984. FAO species catalogue. Vol. 4. Sharks of the world. An annotated and illustrated catalogue of shark species known to date. FAO Fish. Synop., 125: $12-13$.

DAIBER, F. C. 1960. A technique for age determination in the skate, Raja eglanteria. Copeia, 1960: 258-260.

DIAZ-SOLTERA, H. 1999. Endangered and threatened species; revision of candidate species list under the Endangered Species Act. Federal Register, 64(120): 33166-33467.

DU BUIT, M. H. 1977. Age et croissance de Raja batis et de Raja naevus en Mer Celtique. ICES J. Cons, 37: 261-265.

DULVY, N. K., J. D. METCALFE, J. GLANVILLE, M. G. PAWSON and J. D. REYNOLDS. 2000. Fishery Stability, Local Extinctions, and Shifts in Community Structure in Skates. Conserv. Biol., 14 (1): 283-293.

FITZ, E. S. JR. and F. C. DAIBER. 1963. An introduction to the Biology of Raja eglanteria Bosc 1802 and Raja erinacea Mitchill 1825 as they occur in Delaware Bay. Bull. Bingham Oceanogr. Coll., 18(3): 69-97.

FRISK, M. G., T. J. MILLER and M. J. FOGARTY. 2001. Estimation and analysis of biological parameters in elasmobranch fishes: A comparative life history study. Can. J. Fish. Aquat. Sci., 58(5): 969-981.

GELSLEICHTER, J. J. 1998. Vertebral cartilage of the clearnose skate, Raja eglanteria: Development, structure, ageing, and hormonal regulation of growth. Ph.D. dissertation. College of William and Mary, Virginia Institute of Marine Science. $215 \mathrm{p}$.

HOENIG, J. M. and S. H. GRUBER. 1990. Life history patterns in the elasmobranchs: implications or fisheries management. In: Elasmobranchs as a living resources: advances in the biology, ecology, systematics, and the status of fisheries. H. L. Pratt, Jr., S. H. Gruber, and T. Taniuchi (eds.). NOAA Tech. Rep. NMFS 90, 519 p., Pages 1-16.

HOLDEN, M. J. 1972. The growth rates of Raja brachyura, $R$. clavata and $R$. montagui as determined from tagging data. ICES J. Cons, 34: 161-168.

1973. Are long-term sustainable fisheries for elasmobranchs possible? Rapp. d. Cons. Int. Explor. Mer., 164: $360-367$.

1974. Problems in the rational exploitation of elasmobranch populations and some suggested solutions. Pages 117-137. In: Sea Fisheries Research. F. R. H. Jones (ed.). Science, London, $510 \mathrm{p}$.

1975. The fecundity of Raja clavata in British waters. ICES J. Cons., 36(2): 110-118.

HOLDEN, M. J. and M. R. VINCE. 1973. Age validation studies on the centra of Raja clavata using tetracycline. ICES J. Cons., 35: 13-17.

JOUNG, S. and C. CHEN. 1995. Reproduction in the Sandbar Shark, Carcharhinus plumbeus, in the Waters off Northeastern Taiwan. Copeia, 1995(3): 659-665.

KULKA, D. W., K. T. FRANK and J. E. SIMON. MS 2002. Barndoor skate in the Northwest Atlantic off Canada: Distribution in relation to temperature and depth based on commercial fisheries data. DFO Atl. Fish Res. Doc., No. 02/73, $18 \mathrm{p}$.

LEIM, A. H. and W. B. SCOTT. 1966. Fishes of the Atlantic Coast of Canada. Fish. Res. Board Can., Bull. No. 155, $485 \mathrm{p}$.

MARTIN, L. K. and G. M. CAILLIET. 1988. Aspects of the Reproduction of the Bat Ray, Myliobatis californica, in Central California. Copeia, 1988(3): 754-762.

MCEACHRAN, J. D. and J. A. MUSICK. 1975. Distribution and relative abundance of seven species of skates (Pisces: Rajidae) which occur between Nova Scotia and Cape Hatteras. Fish. Bull. U.S., 73(1): 110-136.

MEDIA CYBERNETICS. 1999. Optimus, version 6.5. Media Cybernetics, Silver Spring, MD.

MUSICK, J. A., G. BURGESS, G. CAILLIET, M. CAMHI and S. FORDHAM. 1999. Management of Sharks and Their Relatives (Elasmobranchii). Fisheries, 25(3): 9-13.

MUSICK, J. A. 1999a. Criteria to define extinction risk in marine fishes. The American Fisheries Society initiative. Fisheries, 24(12): 6-14.

1999b. Ecology and Conservation of Long-Lived Marine Animals. In: Life in the slow lane: ecology and conservation of long-lived marine animals. J. A. Musick (ed.). Am. Fish. Soc. Symp., 23, pages 1-10, Bethesda, Maryland. $265 \mathrm{p}$.

NATANSON, L. J. 1993. Effect of temperature on band deposition in the little skate, Raja erinacea. Copeia, 1993: 199-207.

NATANSON, L. J. and G. M. CAILLIET. 1990. Vertebral growth zone deposition in angel sharks an enigma. Copeia, 1990: $1103-1115$.

NEFSC, 2000 [Northeast Fisheries Science Center]. MS 2000. Report of the $30^{\text {th }}$ Stock Assessment Workshop ( $30^{\text {th }} \mathrm{SAW}$ ), Fall 1999. Woods Hole, MA: NOAA/NMFS/NEFC. NEFC Ref. Doc., No.00-03, 477 p.

NEER, J. A. and G. M. CAILLIET. 2001. Aspects of the life history of the Pacific electric ray, Torpedo californica (Ayres). Copeia, 2001: 842-847.

PARENT, S. and L. M. SCHRIMI. 1995. A model for the determination of fish species at risk based upon lifehistory traits and ecological data. Can. J. Fish. Aquat. Sci., 52: $1768-1781$.

POSGAY, J. A. 1957. Sea scallop boats and gear. United States Department of the Interior; Fish and Wildlife Service. Fishery Leaflet, 442, 11 p.

PRATT, H. L. JR. 1979. Reproduction in the blue shark, Prionace glauca. Fish. Bull. NOAA Tech. NMFS, 77: 445-470.

PRATT, H. L., JR. and J. G. CASEY. 1983. Age and growth of the shortfin mako, Isurus oxyrinchus, using four methods. Can. J. Fish. Aquat. Sci., 40: 1944-1957.

RICHARDS, S. W., D. MERRIMAN and D L. H. CALHOUN. 
1963. Studies on the marine resources of southern New England, IX. The biology of the little skate, Raja erinacea Mitchill. Bull. Bingham Oceanogr. Coll., 18: 5-67.

RYLAND, J. S. and T. O. AJAYI. 1984. Growth and population dynamics of three Raja species (Batoidei) in Carmarthen Bay, British Isles. ICES J. Cons., 41: 111-120.

SAS (SAS Institute, Inc.) 1999. SAS/STAT user's guide, version 8. Cary, NC.

SIMON, J.E. and K.T. FRANK. MS 1996. Assessment of the Division 4VsW skate fishery. DFO Atl. Fish. Res. Doc., No. 96/105, 51 p.

SIMON, J. E., K. T. FRANK and D.W. KULKA. MS 2002. Distribution and abundance of Barndoor Skate Dipturus laevis in the Canadian Atlantic based upon research vessel surveys and industry/science surveys. DFO Atl. Fish Res. Doc., No. 02/70, 68 p.

SMALE, M. J. and A. J. J. GOOSEN. 1999. Reproduction and feeding of spotted gully shark, Triakis megalopterus, off the Eastern Cape, South Africa. Fish. Bull., U.S.,
97(4): 987-998.

SPRINGER, S. 1960. Natural history of the sandbar shark Eulamia milberti. Fish. Bull., U.S., 61: 1-38.

STRUHSAKER, P. 1969. Observations on the biology and distribution of the thorny stingray Dasyatis centroura. Bull Mar. Sci., 19: 456-481.

WALKER, P. A. and H. J. L. HEESSEN. 1996. Long-term changes in ray populations in the North Sea. ICES J. Mar. Sci., 53: 1085-1093.

WALKER, P. A. and J. R. G. HISLOP. 1998. Sensitive skates or resilient rays? Spatial and temporal shifts in ray species composition in the central and north-western North Sea between 1930 and the present day. ICES J. Mar. Sci., 55: 392-402.

WARING, G. T. 1984. Age, growth and mortality of the little skate off the northeast coast of the United States. Trans. Amer. Fish. Soc., 113: 314-321.

WOURMS, J. P. 1977. Reproduction and development in chondrichthyan fishes. Amer. Zool., 17: 379-410. 